\title{
Monetary Response of China, South Korea, and Singapore to the Global Financial Crisis: Comparative Analysis
}

\author{
R. Latfullina
}

\begin{abstract}
The global financial and economic crisis approached East Asia in autumn 2008, causing a substantial slowdown of regional economies. To overcome the negative consequences and mitigate the recession, local governments promptly responded to the crisis with monetary measures and fiscal stimuli. The current paper provides a comparative analysis of monetary policy frameworks of selected East Asian countries, i.e. China, South Korea, and Singapore, and examines their monetary response to the global crisis. The results show that despite relatively diverse approaches to monetary policy, all of the economies due to implemented macroeconomic measures have managed to effectively recover from the economic breakdown.
\end{abstract}

Index Terms - East Asian economies, global financial crisis, monetary policy.

\section{INTRODUCTION}

The global financial and economic crisis approached Asia in autumn 2008 causing a substantial slowdown of regional economies. To overcome the negative consequences and mitigate the recession, local governments promptly responded to the crisis with monetary measures and fiscal stimuli. The current paper compares monetary policy frameworks of selected East Asian countries, i.e. China, South Korea, and Singapore, and examines their monetary response to the global crisis. The results show that all of the economies due to implemented macroeconomic measures have managed to effectively recover from the consequences of the economic recession.

The paper proceeds as follows. Section II provides an overview of monetary policy frameworks, including monetary goals, targets, and instruments adopted in China, South Korea, and Singapore. Section III focuses on the transmission of crisis to selected countries and its impact on economic conditions of the states. Section IV studies monetary response of regional economies to the consequences of the crisis and effectiveness of the implemented policies. And finally, the core part - Section $\mathrm{V}$ - concludes the paper with a comparative analysis of monetary frameworks and undertaken policy measures.

Manuscript received April 23, 2014; revised June 23, 2014.

R. Latfullina is with the School of Business and Economics, Friedrich Alexander University of Erlangen-Nuremberg, Nuremberg, 90403 Germany, and with the Faculty of Business Administration, Nuremberg Institute of Technology Georg Simon Ohm, Nuremberg, 90402 Germany (email: regina_ruspb@mail.ru ).

\section{MONETARY POLICY FRAMEWORK}

\section{A. Singapore}

The Monetary Authority of Singapore (MAS) - country's Central Bank - implements its policies with the primary goal of promoting price stability [1]. All monetary activities are carried out under the exchange rate targeting regime. Thus, the MAS endeavors to maintain the trade-weighted Singapore dollar exchange rate, within a certain undisclosed policy band. When the exchange rate exceeds target boundaries, the Central Bank intervenes into foreign exchange markets by purchasing or selling national currency against the US dollar. Information about exchange rate interventions, including time, relative size, and frequency of operations, is not disclosed by the MAS, which is justified by the necessity to have "some constructive ambiguity in the management of the exchange rate" [2].

Due to the fact that the exchange rate has been chosen in Singapore as the focus of country's monetary policy, the control over money supply and domestic interest rate is given up by the Central Bank.

Apart from interventions in the foreign exchange markets, the MAS also makes use of money market operations and liquidity facilities. These monetary instruments are utilized to regulate liquidity in the banking system.

As part of money market operations, the Central Bank employs direct borrowing and lending, concludes foreign exchange swaps and repurchase agreements of Singapore Government Securities, as well as issues MAS bills (since 2011) [3]. In addition to assisting in the sterilization of exchange rate interventions, such activities ensure injection of liquidity or withdrawal of excessive funds from the financial system. Liquidity facilities, i.e. Intraday Liquidity Facility (borrowing funds from the MAS via repo transactions on an intraday basis) and Standing Facility (depositing or borrowing funds from the MAS against collateral on an overnight basis), help to level out daily funding needs of commercial banks and smooth interest rate volatilities.

\section{B. Korea}

The Bank of Korea (BOK) represents the country's main governmental institution responsible for the implementation of monetary policy. In pursuit of price and financial stability, the Korean Central Bank operates an inflation targeting regime with the Consumer Price Index (CPI) being the target indicator. Thus, after considering a wide range of variables such as trends on the financial markets, economic circumstances and forecasts at home and abroad, historical 
inflation changes, etc., the BOK sets inflation targets for a three-year time horizon. Recent inflation targets equaled to $3 \% \pm 0.5 \%$ in the period of $2007-2009$ and to $3 \% \pm 1 \%$ from 2010 to 2012 . Increases within a range were justified by the augmented uncertainty of price levels in the aftermath of the global crisis. Between December 2007 and April 2009, the actual inflation rates exceeded the upper bound of $3.5 \%$ due to rising international oil prices and depreciating national currency. In 2010, the inflation stayed within the target boundaries but rose again to $4 \%$ in 2011 as a consequence of the demand-side pressure and newly increased oil prices. Later in 2012, economic slowdown and stable prices for raw materials and agricultural products induced drop in inflation down to below the lower bound of $2 \%$ [4].

Compliance of the actual inflation rate with the target one is pursued through implementation of the interest rate-based monetary policy. The BOK sets the policy rate, i.e. the Bank of Korea Base Rate, and concentrates on attaining this level while conducting its policy. Apart from being a rate for 7 day loans from the Central Bank to commercial banks, the Base Rate is also used by the BOK as a rate for sales of securities to absorb liquidity.

Main monetary instruments in Korea include open market operations, reserve requirement ratio (RRR), and lending and deposit facilities.

The main purpose of open market operations carried out by the BOK is adjustment of the call rate in accordance with the Base Rate. The goal is approached via issuance of Monetary Stabilization Bonds (normally has long-lasting policy effects due to long maturities of such bonds), securities transaction (purchase or sale of government and public bonds used for withdrawal or injection of liquidity), and deposits with the Monetary Stabilization Account (utilized to regulate short-term liquidity) [4]. The BOK can conduct transactions with individual financial institutions but usually carries out open market operation with the use of online public offerings.

According to reserve requirements, financial institutions are obliged to hold a certain part of their liabilities either as deposits at the Central Bank or as cash in vault. Reserve requirement ratios can only differ according to type and size of liabilities. For instance, money market deposit accounts, housing installment deposits, and workers' housing savings deposits fall under $7 \%, 2 \%$, and $0 \%$ requirement ratios respectively [5]. Normally, reserve deposits by the Central Bank bear no interest.

Lending and deposit facilities of the BOK can function as a liquidity adjustment mechanism and as a lender of last resort. Firstly, the Central Bank determines Aggregate Credit Ceiling as a boundary for the overall refinancing provided to financial institutions. Credit supplied to banks in the form of Aggregate Credit Ceiling Loans encourages them to increase financial support of small- and mediumsized enterprises (SMEs). Secondly, the BOK provides the so called Liquidity Adjustment Loans and Deposits that allow banks to borrow funds in case of temporary liquidity deficiency or deposit excessive funds with the Central Bank. These instruments serve for stabilization of the money market interest rate. Thirdly, the BOK extends special loans as a lender of last resort and supports banks when they face liquidity shortages in the course of the day in a real-time mode through intraday overdrafts.

\section{China}

The Chinese Central Bank, i.e. the People's Bank of China (PBC), pursues two goals: provision of price stability and promotion of long-term economic growth. According to M. Geiger [6], the PBC implements a hybrid monetary approach that targets both the monetary base and the interest rate. Targeting of the latter however is not always efficient due to the developing character of market interest rates in China, which leads to a higher reliance on monetary base targeting. Therefore, money supply M2 (currency in circulation, demand deposits, and quasi-money) is the primary monetary figure for the conduct of the PBC's monetary policy. Meanwhile domestic loan increases and exchange rate changes can be considered as further intermediate targets. Thus, under the current exchange rate regime the Chinese yuan is allowed to fluctuate daily up to $\pm 1 \%$ (as of April, 2012) [7]. Whenever the exchange rate crosses the bound, the PBC intervenes in the foreign exchange market and purchases or sells foreign currencies.

The main monetary instruments applied by the PBC include open market operations, reserve requirement ratio, interest rate instruments, window guidance and some other policy measures.

The PBC carries out open market operations using three types of securities: national bonds, central bank bills, and financial bonds from policy banks [8]. Apart from being traded as outright market operations, these securities are also involved in repurchase agreements and reverse repurchase agreements. The former are carried out for absorbing monetary liquidity, while the latter are implemented for fuelling it. Together with adjustments in reserve ratio requirements, the open market operations have been rather frequently used for sterilization of exchange rate interventions induced by large inflows of foreign currency into the Chinese economy.

The PBC directly influences bank lending and private savings by administering the benchmark deposit and lending rates and demonstrates relatively less reliance on market interest rates. Despite of the ongoing liberalization of interest rates in China, the reform towards market-based interest rates still has a long way to go.

Domestic loan increase is managed primarily via window guidance. Chinese window guidance represents an instrument though which the PBC brings information about its current and future course of action to the notice of commercial banks and insistently persuades them to adhere to the official policy of the Central Bank. Financial institutions that fall under the influence of this monetary instrument include all commercial banks of the country ranging from the four biggest state-owned banks to the smallest local ones. While the PBC head office organizes monthly meetings and ad hoc gatherings with the largest institutions to communicate its policy, regional branches of the PBC implement similar activities with regard to local banks. 


\section{GLOBAL FINANCIAL CRISIS AND ITS IMPACT ON CHINA, KOREA, AND SINGAPORE}

At the time when recession in the United States and Europe was already underway, most Asian economies did not show any sign of possible crisis. Relatively strong macroeconomic fundamentals, reduced exposure to external vulnerabilities, and rather robust balance sheets of financial institutions supported the belief that Asia would successfully avoid economic recession. This view was also backed up by the fact that banking systems of most countries in the region were more of a conservative kind. However, this assumption turned out to be completely wrong. Since September 2008, international financial and economic crisis has spilled over to Asia severely impacting regional economies [9].

The global recession was transmitted to China, Korea, and Singapore mainly through the trade channel. Collapse in world demand led to deterioration of economic conditions in these strongly export-oriented countries. To a lesser extent, negative consequences were also brought about by the worsening of the global financial environment. Thus, during the crisis the available amount of trade finance fell, while the price for it increased sharply. According to a survey conducted jointly by the IMF and Bankers' Association for Finance and Trade, among the banks that participated in the survey more than 70 percent reported the rise in prices for various types of letters of credit and 90 percent noted the price increase of both short- and medium-term lending facilities [10]. As a result, it was export that deteriorated due to disruption of financial intermediation in which banks and financial institutions facilitate trade.

Moreover, the region's strong cross-border production networks intensified the spillover effects of the crisis. Today, almost any production process is dispersed within a network of firms that either have contractual arrangements with each other or belong to transnational corporations. The fact that production is internationally diversified can raise the scope and speed of the spreading of external shocks. Thus, during the current financial crisis firms and companies were affected not only through final demand (a decline in exports), but also through the breach in the flow of inputs received from their suppliers [11]. For instance, the drying up of a credit line of a firm inserted in a larger productive chain did not only affect the production or trade activity of this single firm. Shocks reverberated through the entire supply chain across various sectors and countries, leading to increases in production costs, thus higher prices and lower demand, and curtailing firms' ability to complete their production plans or sell their output.

M Ferrantino and A. Larsen [12] illustrate the idea by the following example: the decline in demand for computers, peripherals, telecommunication equipment, and office equipment in the United States during the recent crisis led to a decrease in Chinese export of these goods to the US. However, computers and cell phones were not actually produced in the country - they were only assembled in China using the components imported from other East Asian economies. Thus, through global supply chains the decrease of Chinese exports reverberated to other countries in Asia by reducing their exports. This circuit closed back in the United States, since it participates in the trans-Asian electronics trade as a provider of semiconductors and other technologyintensive electronic components. So as a result, the decrease in US demand and imports of computers and cell phones led indirectly to a drop in US exports of semiconductors and components, while at the same time negatively affecting trade volumes of Asian economies.

Singapore was the first country in the East Asian region to experience negative consequences of the global financial crisis. The country's economy showed the first signs of recession already in summer 2008 and continued to contract successively in the next four quarters. At the beginning of 2009 when Gross Domestic Product (GDP) fell by $10.1 \%$ (Fig. 1a), Singapore experienced its historically deepest economic downturn [13]. A high share of external demand in total demand (in 2008 it reached 76\% [13]) aggravated the spillover of the global crisis leading to an economic slump in export-oriented manufacturing industries and wholesale trade. The Singapore dollar appreciated vis-à-vis other local currencies intensifying negative impact on country's regional export. In total, Singapore's export (Fig. 2a) collapsed at a very high pace declining by $36 \%$ between September 2008 and February 2009 [14].

(a) Quarterly GDP growth (\% change year-over-year)

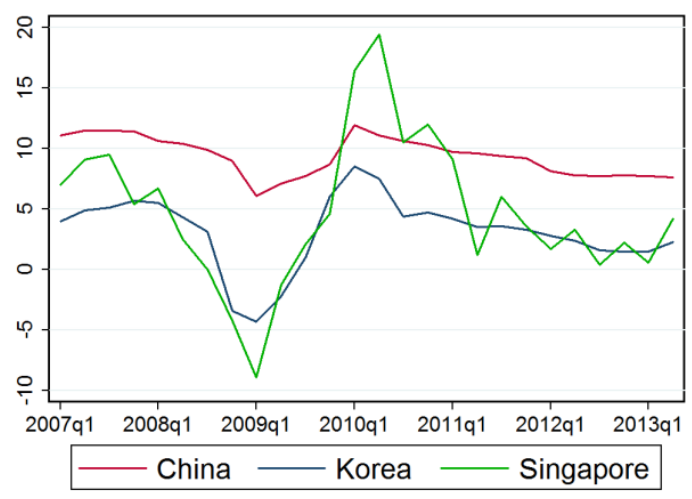

(b) Industrial production (\% change year-over-year)

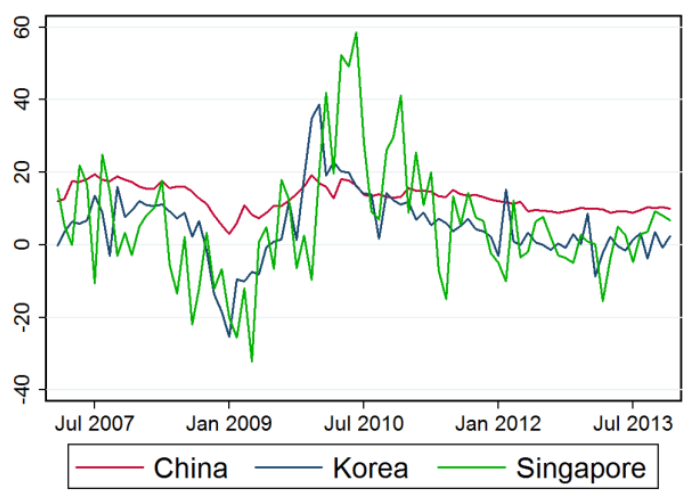

(Data: PBC, BOK, MAS, trading economics)

Fig. 1. Main economic indicators.

Due to the country's relatively well regulated financial market, domestic banks managed to almost entirely avoid problems induced by the US toxic assets. However, the collapse of the stock market generated by the global crisis provoked a massive loss in wealth. Market capitalization dropped significantly (Fig. 3) while the Straits Time Index fell over $50 \%$ by February 2009, as compared to numbers of the end- 2007 [15]. As a result, the country had to encounter reduced consumption and investment, tightened liquidity conditions, and depressed domestic demand. Singapore's labor market was also affected by the crisis: the necessity to 
cut operational costs urged companies to reduce wages, freeze hiring, and increase redundancies.

The economic situation in South Korea at the end of 2008 was no better than in Singapore. Tight financial integration with the rest of the world accelerated the spillover of the crisis to the Korean economy. As worldwide recession was spreading, foreigners started to reclaim their funds out of Korean financial markets. As a result, the latter experienced huge capital outflows causing sizeable depreciation of the Korean won vis-à-vis major currencies (28\% fall against the US dollar (US\$) from August 2008 to November 2008 [16]) and a huge drop in country's foreign reserves (from US\$240 billion at the end of September 2008 to US\$201 billion at the end of December 2008 [17]). Local banks ran into increasing difficulties with foreign currency borrowings and overall lending conditions deteriorated. All these led to credit crunches in the financial markets.

(a) Volume of exports of goods and services (\% change year-over-year)

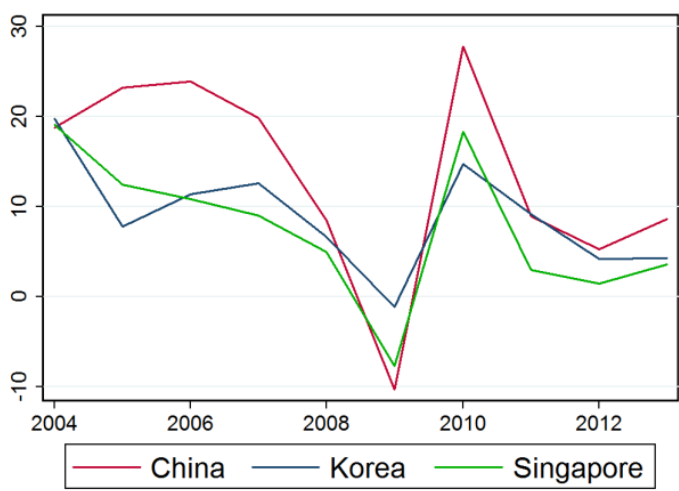

(b) Volume of imports of goods and services (\% change year-over-year)

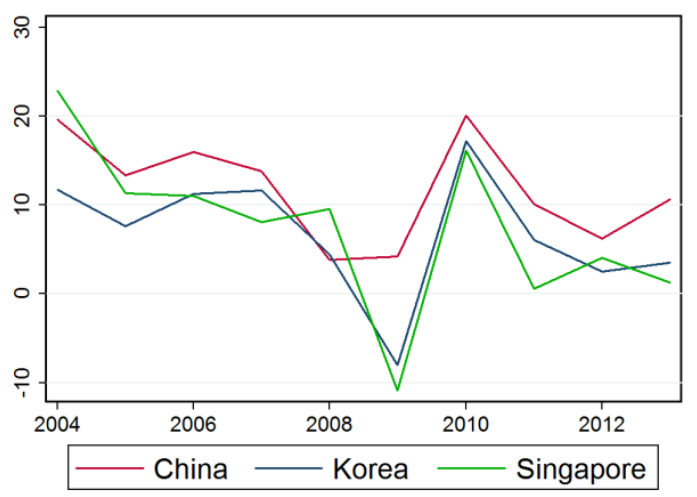

(Data: World bank)

Fig. 2. Trade indicators.

The situation worsened even more due to a huge slump in the country's trade volumes (Fig. 2). The current account as a percent of GDP registered its lowest rate of $0.34 \%$ since 1998 (Fig. 4). Decrease of export revenues and rising concerns about Korea's ability to raise hard currencies intensified pessimistic expectations in the currency market that was already affected by the crisis [17]. During the last quarter of 2008, Korean stock price index (KOSPI) declined by more than $30 \%$, lending to small- and medium-sized enterprises decreased to the level of five times less than that of the third quarter 2008 while unemployment rose from $3.1 \%$ in August 2008 to 4\% in March 2009 [17], [18]. Domestic demand contacted severely leading to a $5.1 \%$ decline of the overall GDP growth (Fig. 1a).

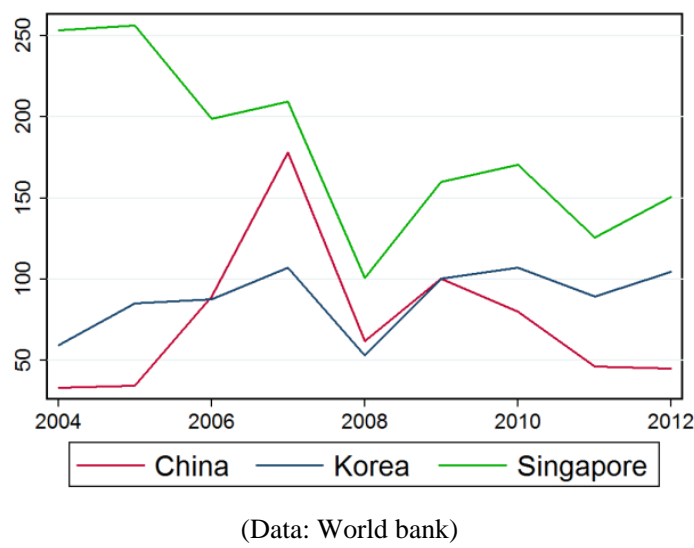

Fig. 3. Market capitalization of listed companies (\% of GDP, yearly).

China started to experience the impact of the global financial crisis in the fourth quarter of 2008. Due to a serious slump in external demand, some industries, especially export-oriented ones, faced the problem of excessive supply. Firms and companies encountered difficulties in production, operation and distribution what negatively affected corporate profits. Urban unemployment increased. Market confidence and expectations weakened significantly. The stock market sank: the total turnover of the Shanghai and Shenzhen Stock Exchanges decreased by 19.34 trillion yuan year on year, the daily turnover went down by 43 percent year on year, and market capitalization dropped by 51.4 percent from the end of 2007 (Fig. 3) [19].

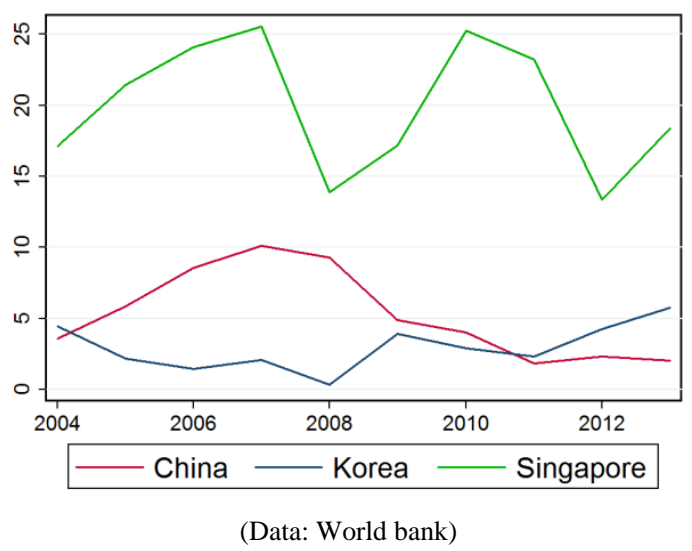

Fig. 4. Current account ( $\%$ of GDP, yearly).

\section{Monetary Response to the Global FinAnCial CRISIS}

\section{A. Singapore}

As most other economies, Singapore responded to the global crisis with both monetary and fiscal policies. However, monetary activities were not that immense as fiscal measures and played relatively smaller role in boosting economic development.

Monetary decisions included above all revision of exchange rate policy and its gradual loosening [20]. Thus, in October 2008 the MAS adopted a zero percent appreciation of the Singapore dollar Nominal Effective Exchange Rate (NEER) policy band. This measure though restored to a certain extent confidence among domestic exporting companies, turned out to be insufficient at the time of 
intensified economic slowdown. The monetary policy was eased further in April 2009 when the MAS re-centered downwards the Singapore dollar NEER policy band in order to match it with the lower level of economic activity in the country. These two measures helped to avoid serious appreciation pressure on the domestic currency during the whole period of economic recovery (Fig. 5).

(a) Singapore dollar NEER index

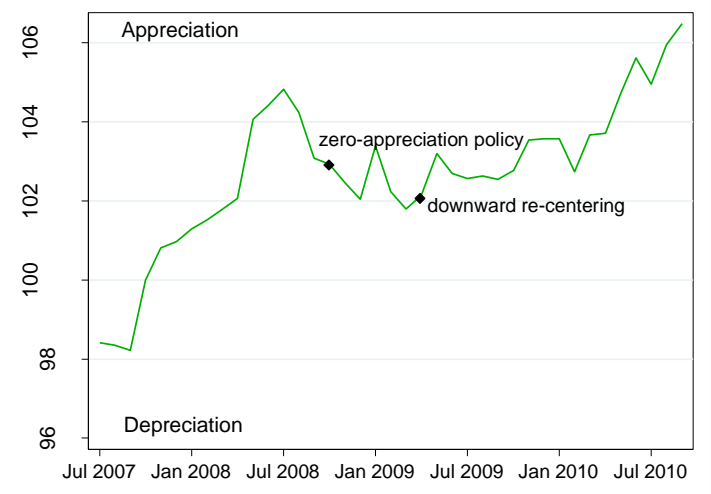

(b) Singapore dollar / US dollar exchange rate

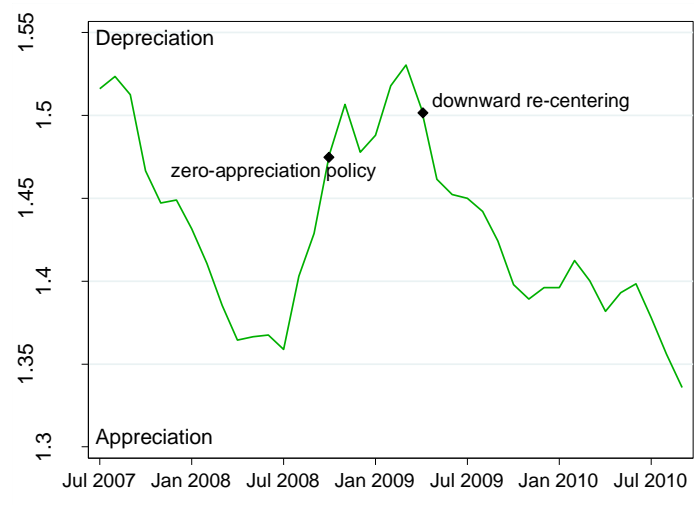

(Data: MAS)

Fig. 5. Singapore dollar exchange rates.

As a response to tightened conditions in funding markets, the MAS used to inject increased amount of funds into the banking system during 2009-2010. Foreign currency liquidity was also raised due to 30 billion US dollar swap agreement signed with the Federal Reserve in October 2008 [21]. Moreover, with the help of fiscal incentives the government triggered a Special Risk-Sharing Initiative comprised of a Bridging Loan Program and a Trade Financing Scheme. The former raised the loan quota from 0.5 to 5 million Singapore dollars and increased the government's share of bank lending risks from $50 \%$ to $80 \%$. While the latter implied assumption of part of the risk in trading finance $(75 \%)$ by the government [22].

Stabilization and recovery of the Singapore's economy took approximately one year. After experiencing a severe downturn at the end of 2008, country's economy expanded year-on-year by $4.6 \%$ in the fourth quarter 2009 and by $16.4 \%$ and $19.4 \%$ in the first and second quarters 2010, respectively [23]. Such a rebound allowed the MAS to tighten its monetary policy by re-centering Singapore dollar NEER policy band upwards in April 2010 and withdrawing excess liquidity in 2011.

\section{B. Korea}

The Bank of Korea implemented a series of measures in order to fight the consequences of the economic recession. From October 2008 to February 2009, the monetary authority lowered its Base Rate on six occasions from $5.25 \%$ to $2 \%$ (Fig. 6). With a time lag, this led to a decline in market interest rates, as well as in banks' lending and deposit rates. The same period also witnessed an injection of 18.5 trillion won through the use of open market operations [24]. This was aimed at stabilization of the financial system and smoothening of capital flows into the money and bond markets.

In order to stimulate credit supply to the economy, the Bank of Korea initiated the following activities: (1) the aggregate credit ceiling was raised by a total of 3.5 trillion won (an increase of more than $50 \%$ ), with interest rate on loans under the ceiling lowered from $3.5 \%$ to $1.25 \%$; (2) financial institutions that subscribed to the Bond Market Stabilization Fund received excess liquidity of 2.1 trillion won; (3) 0.5 trillion won was allotted to banks as a one-off interest payment on their required reserve deposits whereby increasing banks' BIS capital adequacy ratios; (4) 3.3 trillion won was allocated to the Bank Recapitalization Fund that financed the increase of banks' equity capital. [25]

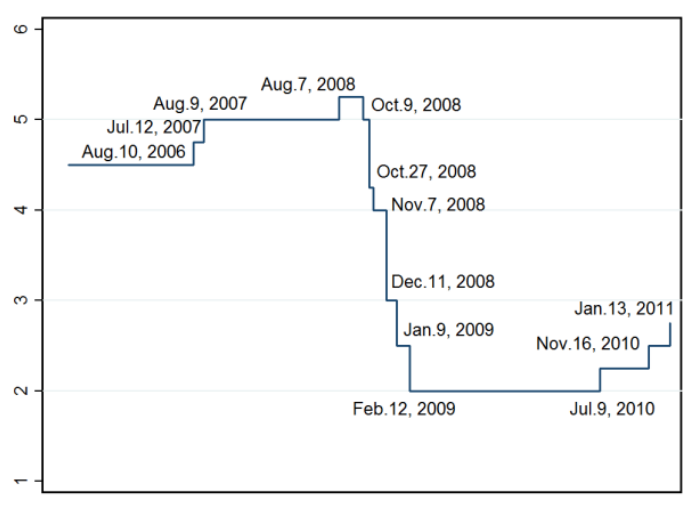

(Data: BOK)

Fig. 6. Adjustments of the BOK base rate.

Stabilization of the foreign exchange market through injection of foreign currency liquidity was another very important priority. Thus, to increase the trade financing attractiveness for SMEs, the Bank of Korea initiated a 10billion US dollar loan scheme; "Foreign Currency Loans Secured by Export Bills Purchased." The project functioned from November 2008 until the end of 2009 and covered all domestic companies. Furthermore, the Central Bank entered into several swap arrangements with the Federal Reserve, the Bank of Japan, and the People's Bank of China in order to raise foreign currency liquidity through the use of proceeds from currency swaps. And finally, domestic export-oriented companies that had earlier concluded currency option contacts to hedge from exchange rate risks were allowed to make foreign currency loans for settlement of such currency options. In total, between October 2008 and February 2009 the foreign exchange market was supplied with 36 billion US dollars through swap transactions and foreign currency denominated loans [26]. 
Implemented policies stirred up rather positive economic developments already in March 2009. Stock prices, as well as market confidence, rebounded while the Korean won maintained an appreciation trend against the US dollar. Domestic demand, as well as exports, kept improving slowly but steadily leading to a gradual recovery of the economy. Positive year-on-year GDP growth of $1 \%$ was achieved in the third quarter of 2009 with the indicator approaching $6 \%$ by the end of 2009 [26].

\section{China}

The reaction of the Chinese government to the new economic situation was a 180-degree-turn of the implemented tightening monetary measures. In order to fight the consequences of the crisis, the PBC started carrying out a moderately loose monetary policy.

First of all, the one-year benchmark deposit and lending rates were cut down on five occasions since September 2008, from $4.14 \%$ to $2.25 \%$ and from $7.47 \%$ to $5.31 \%$ respectively [27]. These measures were aimed at stimulation of domestic demand and credit lending. The PBC further lowered the deposit rates of excess reserve and statutory reserve, as well as the rediscount rate. The latter was reduced cumulatively by $2.52 \%$ so as to encourage a more vigorous use of paper financing by commercial banks, whereby allowing smalland medium-sized enterprises increasingly use this instrument as a short-term financing channel. In general, paper financing augmented by 650 billion yuan in 2008, with the highest increment registered in the second half of 2008 [28].

Secondly, in order to release liquidity in the banking system, the PBC reduced the amount of open market operations and lowered the reserve requirement ratio for both small and large financial institutions on four occasions. The former experienced a $4 \%$ cumulative cut of the reserve requirement ratio, while the latter - a $2 \%$ cumulative decrease. With the help of such measures, by the end of 2008 the PBC managed to release 800 billion yuan of liquidity [29]. Whereas, the excess reserve ratio of financial institutions went up to $5.11 \%$, representing a $1.81 \%$ increase from the end of 2007 [28].

Thirdly, the PBC revised credit programming of commercial banks. Financial institutions were encouraged to wisely extend credit support to the real economy. Industries however were treated on a differentiated basis. Preferential financing was provided to the agricultural sector and the services industry, SMEs, civil well-being projects, scientific and technological innovation, etc. In November and December of 2008, new loans amounted to 476.9 billion yuan and 771.8 billion yuan respectively [28].

In November 2008, the Chinese government announced ten measures to promote economic growth. Monetary measures reinforced by pro-active fiscal policies were primarily aimed at boosting domestic demand and counterbalancing significant drop in exports. The economic stimulus package included investment of four trillion yuan (approximately 585 billion US dollars) into the country's economy [29].

During the following year (2009), governmental macroeconomic policies maintained their focus on economic recovery and continued to include a mix of moderately loose monetary measures and pro-active fiscal activities. By the end of the year, Chinese main economic indicators had not reached the pre-crisis level but were not far from approaching the previous numbers: the recovery of the economy was going on rather rapidly. Thus, country's GDP in 2009 amounted to 33.5 trillion yuan representing $8.7 \%$ growth rate year on year basis [28]. By the year-end, country's export and import still showed a decline from lastyear indicators but continued to improve on a monthly basis. Economic recovery was supported by continuous growth of investment, consumption and industrial output. Positive results were also showed by the Chinese equity market: Shanghai and Shenzhen Stock Exchanges almost doubled their market value since the end of 2008 [28], The Shanghai Composite Index experienced a $78 \%$ increase, while the Shenzhen Component Index showed a more than $100 \%$ boost. Even though unemployment rate stayed almost unchanged, creation of more than 10 million new jobs in urban regions prevented further worsening of the labor market [29].

\section{COMParative Analysis of Monetary Policies}

The profiles of three East Asian economies - Singapore, South Korea, and China - significantly differ from each other in a wide range of characteristics, e.g. size, economic growth and development, population numbers, openness of the economy, development of financial markets, level of industrialization, informatization and urbanization, etc. And it is not surprising that monetary frameworks and policies of these countries vary as well. Thus, the small size of its economy and strong openness to international trade and capital flows justify Singapore's exchange rate targeting regime. Interest rates are not regulated by the MAS and are mainly determined by "foreign interest rates and investor expectations of future movements in the Singapore dollar" [30]. This is absolutely not typical for the Korean and Chinese economies. Having chosen inflation targeting as its monetary framework, the Bank of Korea implements an interest rate-based monetary policy and focuses on maintaining the desired Base Rate level whereby guiding market interest rates. This could have worked also in China if market interest rates in the country were as liberalized as those in Korea. However, the Chinese market-based interest rate reform is still in progress. And this to some extent makes it reasonable to employ monetary targeting with money supply (M2) being the main intermediate goal. However, the domestic loan increase and the exchange rate also play a certain role as monetary targets.

Apart from diverse policy frameworks, the Central Banks of the selected countries have in addition various toolkits at their disposal. The widest variety of monetary instruments is utilized by the PBC. Some of the tools, e.g. window guidance, are hardly employed on the same scale by any other country in the world. Other instruments are rather conventional, for instance open market operations or reserve requirement ratio. The latter however is applied on a much larger basis than the same instrument in Korea. The Chinese reserve requirements also bear country-specific characteristics. Thus, as opposed to the Korean system where reserve requirements differentiate only according to 
type and size of banks' liabilities, the reserve requirement ratio in China can vary across financial institutions that have different size, geographical position, or institutional range. A banks' capital adequacy ratio and asset quality are also taken into consideration.

Lending facilities of the MAS and the Bank of Korea share similar features in a sense that they are primarily used as liquidity adjustment mechanisms. However, two Central Banks differ in their choice of the primary monetary instrument. Singapore's monetary policy rests upon exchange rate interventions while that of Korea focuses above all on managing the Central Bank policy rate.

Monetary responses of China, Korea, and Singapore to the global financial crisis were in strong compliance with monetary policy frameworks of the respected countries. However, the magnitude of implemented measures varied across economies. Thus, a relatively modest response was demonstrated by the Monetary Authority of Singapore. Two adjustments of the exchange rate policy band and some liquidity injections into the banking system were the main monetary measures carried out by the MAS. As opposed to monetary activities, budgetary measures played a much more significant role. Nevertheless, the country's economy managed to recover without significant currency depreciation.

Monetary activities of the Korean and Chinese Central Banks during the financial crisis were relatively intense. A significant effort was put forth in order to stimulate credit supply in the economy. In Korea, this was done through the rise of the aggregate credit ceiling, interest payments on reserve deposits, and provision of banks with excess liquidity. The PBC on its behalf reduced the benchmark deposit and lending rates, injected liquidity via RRR cuts and communicated to commercial banks the necessity to extend credit support through window guidance. Thus, in spite of having a similar goal, the implementation mechanism was different in the two countries.

Rather strong concerns were generated in Korea due to sizeable depreciation of the domestic currency. That is why stabilization of the foreign exchange market was one of the Central Bank's priorities. In contrast to the Singapore dollar that was regulated by the MAS via direct exchange rate interventions, the Korean won was manipulated by the Bank of Korea indirectly through injection of foreign currency liquidity into the foreign exchange market.

Table I summarizes the main differences in institutional arrangements and implementation mechanisms of the Chinese, Korean, and Singaporean monetary policies. Despite rather diverse approaches, all of the economies due to implemented macroeconomic measures have managed to recover from the consequences of the global financial crisis.

Further research might explore the link between countries' characteristics, inter alia economic and financial conditions, political features, geographical indicators, and the choice of monetary policies, i.e. monetary goals, targets, and instruments.

Thus, the comparative analysis of monetary policies in China, Korea, and Singapore shows that for a small and open economy with a high reliance on international trade, targeting of the exchange rate and exchange rate interventions appear to be rather successful when implementing monetary policy. Targeting of money supply as well as utilizing a larger variety of monetary instruments suit countries which financial systems are still under development and liberalization. Moreover, governmental control over monetary operations and strong hierarchical system with strict adherence to orders of higher-ranking officials make certain instruments, e.g. window guidance, indeed effective. Finally, economies with developed financial institutions and relatively liberalized market interest rates might find it rather attractive to target inflation and implement interest rate adjustments as one of the main monetary activities.

TABLE I: COMPARISON OF MONETARY POLICIES

\begin{tabular}{|c|c|c|c|}
\hline & Singapore & Korea & China \\
\hline $\begin{array}{l}\text { Main Policy } \\
\text { Goal }\end{array}$ & price stability & $\begin{array}{c}\text { price and } \\
\text { financial stability }\end{array}$ & $\begin{array}{l}\text { price stability and } \\
\text { economic growth }\end{array}$ \\
\hline \begin{tabular}{|l} 
Monetary \\
Framework \\
\end{tabular} & $\begin{array}{c}\text { exchange rate } \\
\text { targeting }\end{array}$ & inflation targeting & $\begin{array}{l}\text { monetary } \\
\text { targeting }\end{array}$ \\
\hline $\begin{array}{l}\text { Intermediate } \\
\text { Target }\end{array}$ & exchange rate & base interest rate & $\begin{array}{l}\text { money supply } \\
\text { (M2) }\end{array}$ \\
\hline $\begin{array}{l}\text { Central Bank's } \\
\text { Control over } \\
\text { Interest Rate } \\
\end{array}$ & No & Yes & Yes \\
\hline $\begin{array}{l}\text { Monetary } \\
\text { Instruments }\end{array}$ & \multicolumn{3}{|c|}{ vary across countries } \\
\hline $\begin{array}{l}\text { Main Monetary } \\
\text { Response to the } \\
\text { Global Crisis }\end{array}$ & $\begin{array}{c}\text { exchange rate } \\
\text { interventions; } \\
\text { liquidity } \\
\text { injections }\end{array}$ & $\begin{array}{c}\text { Base Rate } \\
\text { adjustments; } \\
\text { liquidity } \\
\text { injections; foreign } \\
\text { currency liquidity } \\
\text { injections; } \\
\text { stimulation of } \\
\text { credit supply }\end{array}$ & $\begin{array}{c}\text { benchmark } \\
\text { deposit and } \\
\text { lending rates } \\
\text { adjustments; RRR } \\
\text { adjustments; } \\
\text { liquidity } \\
\text { injections; } \\
\text { stimulation of } \\
\text { domestic demand; } \\
\text { stimulation of } \\
\text { credit supply }\end{array}$ \\
\hline $\begin{array}{l}\text { Fiscal Stimulus } \\
\text { Package }\end{array}$ & Yes & Yes & Yes \\
\hline $\begin{array}{l}\text { Effective policy } \\
\text { response? }\end{array}$ & Yes & Yes & Yes \\
\hline
\end{tabular}

\section{ACKNOWLEDGMENT}

The author would like to thank Prof. Dr. Uwe Mummert and Prof. Dr. Helen Rogers for their excellent comments. The author is solely responsible for the analyses and conclusions expressed in this paper.

\section{REFERENCES}

[1] Monetary Authority of Singapore, "Monetary policy operations in Singapore," Mar. 2013.

[2] O. C. Tee, "An exchange-rate-centred monetary policy system Singapore's experience," in Market Volatility and Foreign Exchange Intervention in EMEs: What has Changed? BIS Papers no. 73, pp. 307-316, Oct. 2013.

[3] Monetary Authority of Singapore, "Monetary policy operations in Singapore," Mar. 2013.

[4] C. Kim et al., Monetary Policy in Korea, edited by M. Kim, Seoul: Hongjin CTP \& Printing Co., Ltd, 2012.

[5] Bank of Korea, "Monetary policy report," Mar. 2009

[6] M. Geiger, "Monetary policy in China: institutions, targets, instruments and strategies," Ph.D. dissertation, Dept. of Econ., Wuerzburg Univ., Wuerzburg, Germany, 2010.

[7] R. Sun, "Does monetary policy matter in China? A narrative approach," China Economic Review, vol. 26, pp. 56-74, Sep. 2013.

[8] M. Geiger, "Monetary policy in China: institutions, targets, instruments and strategies," Ph.D. dissertation, Dept. of Econ., Wuerzburg Univ., Wuerzburg, Germany, 2010. 
[9] International Monetary Fund. (2009). World Economic Outlook: Crisis and Recovery. [Online]. Available: http://www.imf.org/external/pubs/ft/weo/2009/01/pdf/text.pdf

[10] T. Dorsey, "Trade finance stumbles," Finance and Development, pp. 18-19, Mar. 2009.

[11] H. Escaith and F. Gonguet, "International Trade and Real Transmission Channels of Financial Shocks in Globalized Production Networks," WTO Staff Working Paper, ERSD-2009-06, May 2009.

[12] M. J. Ferrantino and A. Larsen. (November 27, 2009). Transmission of the global recession through US trade. [Online]. Available: http://www.voxeu.org/index.php?q=node/4296

[13] Monetary Authority of Singapore, “Annual report,” 2008-2009.

[14] V. Sharma. (2013). Global financial crisis: impact on Singapore and policy measures taken to counter it. A policy brief. [Online] Available: http://de.slideshare.net/VikasSharma128/singapore-gfc vikasmar2013draft

[15] M. L. M. Hui and J. Maru, "Financial liberalization and the impact of the financial crisis on Singapore," TWN Global Economy Series, vol. $24,2010$.

[16] H. C. Chung, "The Bank of Korea's policy response to the global financial crisis," in the Global Crisis and Financial Intermediation in Emerging Market Economies, BIS Paper, no. 54, pp. 257-266, Dec. 2010.

[17] D. Cho, "Responses of the Korean economy to the global crisis: another currency crisis?" presented at the EWC/KDI Conference "Global Economic Crisis: Impacts, Transmission, and Recovery," Honolulu, Hawaii, Aug. 19-20, 2010.

[18] K. Kim, "Global Financial Crisis and the Korean Economy," in Proc. Asia Economic Policy Conference, Santa Barbara, California, Oct. 19-20, 2009, pp. 277-284.

[19] People's Bank of China, "China Monetary Policy Report," Quarter Four 2008.

[20] O. C. Tee, "An exchange-rate-centred monetary policy system: Singapore's experience," in Market Volatility and Foreign Exchange Intervention in EMEs: What has Changed? BIS Papers, no.73, pp. 307-316, Oct. 2013.

[21] Monetary Authority of Singapore. Monetary Authority of Singapore Announces Extension of Swap Facility with US Federal Reserve. Press Releases [Online]. Available: http://www.mas.gov.sg/news-andpublications/press-releases/2009/mas-announces-extension-of-swapfacility-with-us-federal-reserve.aspx

[22] T. J. Liang. (2010). The global financial crisis and policy responses. [Online]. Available:
https://www.cscollege.gov.sg/Knowledge/Pages/The-GlobalFinancial-Crisis-and-Policy-Responses.aspx

[23] Monetary Authority of Singapore, Monthly Statistical Bulletin, Oct. 2010.

[24] I. Huh, "Korea's monetary policy responses to the global financial crisis," KIEP Working Paper, no. 12-05, Dec. 2012

[25] C. Kim et al., Monetary Policy in Korea, edited by M. Kim, Seoul: Hongjin CTP \& Printing Co., Ltd, 2012.

[26] Bank of Korea, "Monetary policy report," Mar. 2009

[27] People's Bank of China, "China Monetary Policy Report," Quarter Four 2008

[28] Xinhuanet. (2009). Backgrounder: China's pro-active fiscal policy and moderately loose monetary policy. [Online]. Available: http://news.xinhuanet.com/english/2009-12/27/content_12711041.htm

[29] People's Bank of China, "China Monetary Policy Report," Quarter Four 2008

[30] Monetary Authority of Singapore. Singapore's exchange rate-based monetary policy. [Online]. Available: http://www.mas.gov.sg/ /media/MAS/Monetary\%20Policy\%20and\% 20Economics/Monetary\%20Policy/MP\%20Framework/Singapores\% 20Exchange\%20Ratebased\%20Monetary\%20Policy.pdf

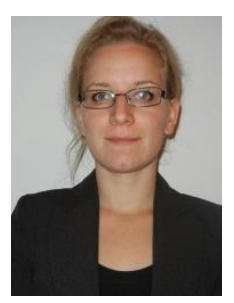

R. Latfullina is a Ph.D candidate at the Friedrich Alexander University of Erlangen-Nuremberg in Germany. She was Born in Saint Petersburg, Russia in 1988, she completed her bachelor's and master's degrees in International Relations at Saint Petersburg State University Russia in 2009 and 2011, respectively. She also obtained M.Sc. degree in international finance and economics from the Nuremberg Institute of Technology Germany in 2012. Current research interests are focused on the international spillover effects of monetary policies as well as the economic developments in East Asia.

Apart from writing her doctoral thesis, she works as a teaching assistant at the Nuremberg Institute of Technology as part of the "Quality Pact for Teaching" team. This is a joint program of the Federal Government and the German States that is aimed at improvement of study conditions and quality of teaching and mentoring for students at institutions of higher education. 